HStud 23 (2009) 1, 47-57

DOI: 10.1556/HStud.23.2009.1.5

\title{
AUTOBIOGRAPHICAL READING: A NEW APPROACH TO THE GENRE IN 20TH CENTURY HUNGARIAN LITERATURE
}

\author{
ISTVÁN DOBOS \\ University of Debrecen, Debrecen \\ Hungary
}

\begin{abstract}
This paper delineates critical approaches to the reading of autobiographical writings that make no presumptions concerning the identity of language and subject or the identity of narrating self and narrated self. It proposes readings that posit the act of narration as a creative gesture through which the narrated self is constructed through the figures of language rather than described as an essence that preceded narration.
\end{abstract}

Keywords: autobiography, memory, recollection, narrative, self, staging, representation, identity

This paper proposes an innovative approach to the reading of 20th century Hungarian autobiographies by placing emphasis on theoretical considerations. ${ }^{1}$ The choice of subject matter is justified first and foremost by the fact that the conditions for the reinterpretation of autobiographical texts of belletristic value went through a fundamental change at the turn of the millennium. This development was due in part to reconsideration of aspects of language and subject prompted by a turn in the interpretive potentials of literary scholarship and in part to the postmodern rewriting of this genre of self-interpretation. ${ }^{2}$ In this context it is the destruction and re-creation of binary concepts related to the genre that prescribes the aspectual framework for the reading of autobiographies. The legitimacy of the contraposition in literary works between the factual and the fictitious, recollection and imagination, signifier and signified, language and reality, image and representation, and the intra-textual and extra-textual worlds has become questionable.

Reader expectations concerning the referentiality of literature have also gone through a significant modification. They have rendered invalid the premises for a contrast between reflection, mimesis, and creation. They have also nullified the basis for the distinction between the intra-textual and the extra-textual. Thus, the purpose of reading can hardly be a restoration of a perfect correspondence between text and a previously established image of the author, since it is also far from obvious to what extent the autobiographical subject may be considered defi- 
nite and particular prior to narration. The texts affixed to the autobiographies, the books published under the name of the author, and the interpretive systems constituting the entire lifework of the author may not replace readings that focus on the poetic qualities of autobiographical writing(s). In the following, I offer a quick list and delineate the major analytical aspects of an approach to reading that focuses on the language-based means of the representation of the self.

\section{Language and Subject}

Taking the notion of a personality existing in the medium of language as a point of departure does not necessarily entail the acceptance of the theoretical insight concerning the nothingness of the subject, ${ }^{3}$ yet it does trigger the concept of the autobiographical self taking form in a text of recollection.

Human memory retains the acquisition of the surrounding world in the form of language, in which process the image of reality (l'image du réel) is created by acts of imagination and the experience obtained through the learning of names of entities, together with perception. According to Lejeune, the opening question in the case of autobiographical reading is not entirely legitimate from the perspective of the nature and the retention of memories. An image recorded in our memory can hardly be made to correspond with the object of contemplation prior to the form of written language. Language is the source, the carrier, and the re-creator of memories, so it would be a mistake to assume that, unlike fiction, autobiography reports events that preceded language. The items in the following list all support the notion that we must keep the possibility of rhetorical reading open: metaphorical descriptions of the world that vanished with the passing of childhood (an ever-recurring setting of autobiographical stories); the variations of language based self-reflection, the forms of its reaction to the readability of the text and perceptual modes towards images that figure as substitutes for the autobiographical self; in short, all those language based events that restrict anthropomorphic readings ${ }^{4}$ and essentially demonstrate the unpredictability of the formation of meaning. ${ }^{5}$

It is precisely through the attempt to establish unity between language and the subject that autobiography, aspiring towards a presentation of the self, achieves its unstated goal by making the gap between the forms of utterances about the narrator and those created within the narration accessible for interpretation as language based acts. The examination of the use of language makes the rift between intended meaning and actual saying, or the incomparability of sagen and Meinung (which is closely related to the difference between the said self and the intended self), accessible to the reader. ${ }^{6}$ The tension arising between the self as the cognitive object of narration and the self taking form in the text calls for an epitaphic 
reading of the autobiographical subject doubled by the creative operation of language. This is illustrated by Bettina Menke in her book on prosopopoeia, to cite one example. ${ }^{7}$

As regards the manifestations of the assumed referential relationship between the author and his/her equivalent in the text, the sameness of the two subjects cannot be taken for granted because of the act of representation. Thus, even the author cannot take full responsibility for the statements made in the text. After all, the referential value of confessional forms of utterances cannot be identified by referring language beyond language. ${ }^{8}$

\section{Staging the Self: The Inter-Replacing Play of Image and Representation}

It is almost essential that narrators reproduce the narrated self in the state of crossing the border towards changing their identity. ${ }^{9}$ Writers of autobiography attain their selves through the other, or the double. For one who recollects, the staging (la mise en scène, Inszenierung) of the self offers an opportunity to relive his/her old self while changing his/her own identity through confrontation with the possibilities surfacing in it. ${ }^{10}$ It would be a mistake to consider this production simple role-playing, which would weaken the impression of the factual credibility of the narration. The fact is that the changing self-understanding of an autobiographer postulates a continuous process of losing and re-creating identity over the course of recollection. The "recollector" establishes his/her identity through the staging of the recollected self, the fundamental condition of which is precisely the need to get distance from him/herself. What happens in the process of autobiographical reading is the mutual substitution of the doubled subjects. The mirror metaphor is somewhat misleading for the purpose of identifying the persons generated during these recurring metamorphoses, as we may assume the presence of relationships between images and their representations which are far more complex in the context of language than in the case of simply facing a mirror.

Fictitious events occurring in life, which are almost inseparable from a writer's modus vivendi, become essential parts of the world of an autobiographer, who alternates between his/her roles. It is not unusual that even the narrated autobiographical self is willing to change roles, too, and concomitantly to create an alter that replaces and expresses the ego in order to be able to contemplate itself in that other. In this case, the self generates itself with the help of what for others constitutes an imaginative act.

The above argumentation can be summed up in the following statement: the basic endeavor of an autobiographer to re-understand his/her own identity can be carried out as an act of staging. 


\section{The Relationship between the Narrating and the Narrated Autobiographical Selves: Encountering the Inconclusiveness of Self-Interpretation}

None of the 20th-century Hungarian autobiographies making up the canon would fully satisfy the most important requirements of "the autobiographical contract." 11 The criterion of the sameness of the author, narrator, and protagonist cannot be satisfied among the overall conditions of the rhetoric of forms in the case of autobiographies that render the personal life of the narrator in the form of recollections. Depending on the span of recollections, the changing time relations, and the systems of evaluation, we need to assume the presence of a multiplicity of constructed and destructed self-formations in the narrative. The shared identity of the persons involved in the "autobiographical contract" also presupposes the sameness of the narrating and the narrated selves. In the case of narratives of recollection, this effect can best be achieved through the introduction of the perception and mode of thinking of the recollected consciousness into the perceptual reach of the recollecting self. However, the gap between the two separate selves will not disappear because of the unyielding difference resulting from temporality. Any present tense recollection of past events can withdraw the narrator from the course of recollection only temporarily, while the doubling of the narrators (i.e., the termination of the continuity of the recollecting and recollected consciousnesses) seems unavoidable when returning to the present of the writing.

Instead of representing the personal life of the narrator, autobiographies can also be about something else, namely, about roles and parts played in belletristic and critical works and writings. The veracity of these may not be compared to the authenticity of actual events, so the author cannot accept responsibility for them by providing his/her own signature. According to Lejeune, suspicion concerning the contentions of individual authors is a constant concomitant of the reading process. In the case of autobiographies, it is the stated identity of the persons that becomes doubtful, while in the case of the reception of fictitious stories, it is the difference between the author and the protagonist that is thrown into question. The declaration of shared identity prompts readers to look for differences, while the assumption of separateness inspires them to search for similarities. The interpretation of autobiographies can be significantly influenced by the reader's recognition of the fact that the narratives do not necessarily assert the presence of continuity between the formations of the autobiographical subject. The readers can hardly find a means to verify the similarities or resemblance (ressemblance) between the narrator, the narrated self, and the authorial self, outside the narrative. The so-called referential contract or agreement with the readers does not mean that the autobiographer guarantees the verisimilitude of the image of reality (vraisemblance). Instead, it rather refers to the notion that the narrator reconstructs the 
story of his/her own life from the unique perspective of the entity that actually experienced it, or as Lejeune writes, "la vérité sur tel aspect de ma vie, ne m'engageant en rien sur tel autre aspect". ${ }^{12}$ Lejeune does not go further than this when he draws the borderline between biographies and autobiographies. The distinction between the factual and the imagined and the real and the veritable ultimately depends on the personal perspectives of the person who actually lived through and now looks back on the events.

The most important token of the contract/agreement is the analogy present in the names, which according to Lejeune constitutes the basis for the similarity between the author in the biographical sense and the person speaking in the text. Unfortunately, I do not have enough space in the present paper to provide detailed arguments for the contention that the problem of the identity of voices in autobiographies poses much more complicated questions than this. I would just like to note briefly how Derrida, on the one hand, distances proper names from their origins by referring the "spatialization" of the sign to the name and, on the other hand, opens up a way for the double readability of the signatures by assuming the existence of fictitious and real signatures. The readers, by taking just the signatures as a point of departure, cannot convincingly decide whether they are reading a belletristic or an autobiographical text. The dual readability of the signatures deprives the name of the author of its unconditional authority, the utmost token of the autobiographical contract/agreement, as long as it connects the voice speaking in the text and the author in the biographical sense on the cover of the book. ${ }^{13}$ The kind of autobiographical writing that stages the self necessarily overwrites the factual biographical elements. The facts of birth or even one's proper name are not exceptions to this, either. In sum, we can say that the source of truth expressed in autobiographies is not the factual veracity indicated by the signature provided.

It seems necessary to reinterpret the relationship between the narrating and the narrated autobiographical selves on the basis of the experience of the inconclusiveness of self-interpretation. For a proper distinction of the meanings of the notions, one point of departure could be Georg Misch's comprehensive history of autobiographical writing. According to the approach of the author of this widely acknowledged manual, a normative characteristic of the works of St. Augustine, Rousseau, and Goethe, as creators of fundamental patterns of the European brand of the genre, is that the autobiographers undertake the task of introducing the facts of the path of the life in question and illustrating its symbolic meaning at the same time. The value or merit of representing life in its complete form is determined by the expansiveness of the worldview and the depth and the universal quality of self-understanding, in short, the so-called "objective truth-value" of the work. The moral truth manifested in the empirical events of the life experience is provided with a symbolic meaning when it is summarized in the closing of the life story. This symbolic meaning is based on a balanced and harmonic relationship 
between the I and the world, i.e., subject and object, the comprehension of which leads the autobiographer to the climax of his/her life in the work. In works that satisfy the autobiographical requirements, the metonymic and metaphoric conclusions overlap, the ending of the story coincides with the symbolic ending point of the self-narrative, the consummated self-understanding. All of the above may be summed up from the aspect of the opening question as follows: the narrator undertakes the task of representative self-portrayal following the summary of the meaning of the life story.

The experience of the inconclusive quality of self-interpretation has a different application in de Man's reading of Rousseau. Here, it recognizes the mechanical functioning of the text in the paradigmatic act of accidental and incidental events that do not fit the system by following an infinite sequence of mutual replacements. This mechanical functioning displays no decipherable operating principle. As he points out, the consequent language based incident cannot be deduced from the system of tropes, and thus the meaning remains separated from the text. The uncontrollable creative functioning of language exerts some influence on the confession, too, as it becomes a textual allegory of the mechanical acts of apologizing in the reading.

\section{Memory and Identity}

The autobiographical narrator creates his/her identity in his/her personal recollections and, by signing his/her name, vouchsafes for the re-understanding of the heritage to which it belongs.

In the complex perspectual movements of recollections, an interaction between recollecting and recollected consciousnesses has to be assumed. As a result, memory and imagination may not be distinctly separated from one another. From the aspect of the demand for the expression of the autobiographical subject, it is an issue of secondary importance whether the truthfulness of the narrated events can be factually verified. Fictitiousness and factuality, imagination and recollection are not mutually exclusive notions when we consider the recollected consciousnesses and the memory of the narrated autobiographical selves. As regards the accessibility of texts, it is perhaps more expedient to refer to various language based, rhetorical, and narrato-poetical modes and methods of establishing a personal past in the examples of Hungarian autobiographical writing in the 20th century. The borderlines for the fictive quality are not set by the authenticity identified with factuality but only by the realization of the expression of the narrated autobiographical self created in the text.

The origins are connected to the names, and a study of this requires the autobiographer to learn the meaning of the names. The actual goal of the inclusion of 
narratives of family history into the course of recollections is to search for substitute representative images. The autobiographers create their self-portraits through an examination of the representative portraits retained from the familial store of recollections. In the play of mutual substitutions and replacements, the personality of the autobiographical narrator is divided among the representative selves, as it were. As I have pointed out above, the distinction between the factual and the imagined and the real and the veritable depends on the personal perspectives of the person who actually lived through the events and now looks back on them.

Autobiographical writing stages the genuine difference we may assume to be present between the recollecting and the recollected selves, and is not satisfied with the reflection of the dissimilation of the two different selves. The changing identity of the autobiographical personality reveals itself in the collisions and conflicts of language-based worlds that express various consciousnesses. The difference in the language versions of autobiographical writings can also be traced back to the fact that the (self-)identity of the narrator is inseparable from his/her recollecting activity, and that memory recollects and preserves not only the stories but also the languages that can be used to give voice to them. ${ }^{14}$

The interactions between time, memory, and identity can be illustrated by the fact that autobiographers may relate individual stories in several different versions. The possibility of re-writing personally related stories may call our attention to the fact that there are sense possibilities unfolding in the act of recollection which are complex formations in the process of establishing personal identities.

\section{Inserted Autobiographical Discourses and Self-Interpreting Configurations}

It is through the gaps between the narrated self-interpretation of the narrator and the text of the autobiographical narrative that readers can find the path towards perceiving the conflicts resulting from the opening up of the sense possibilities of what has been narrated. The dramatization or the staging of the changes in personal thinking is worthy of special attention in the examination of the relationship between the perspective and the voice that can be rendered to the narrator.

The autobiographical writings of the time period in question almost without exception contain self-interpreting formations and configurations that allow for the possibility of a kind of reading that focuses on the poetic qualities of the texts. ${ }^{15}$ These inserted discourses multiply the potential referential systems of the narrative. As a piece of embedded discourse, an actual or recollected diary makes the boundaries between the textual worlds created at different points in time relative and easy to cross. 
A section of an earlier autobiographical text cited in the recollection or the summaries and interpretations of the works of the "author" present in the story being narrated are to be considered as other texts and not simply as mirrors in which the autobiographical narrator rediscovers him/herself. The autobiographers devise a role of a co-creator for the readers in the process of the reading of the faces/images reflected in one another. The re-reading of the sections of diaries, notes, or autobiographical drafts that tend to surface unexpectedly allows for a play among the different perspectives of interpretation.

The preliminary announcements concerning the modes of the narration of the autobiographical subject, together with their potential inherent contradictions, direct the attention of the readers to the relationship of the rhetorical strategy of statement and text. From a narrato-poetical perspective, this first of all means the study of the relationship between the narrator's self-interpreting activity, the narrator's articulation or pronouncement, and the narrated consciousness.

\section{The Experience of Estrangement}

Paul de Man noted that it is in one's mother tongue, considered to be the most familiar medium, that the estrangement of language can be experienced in the most powerful fashion. ${ }^{16}$ Shoshana Felman considered the failure of translation as a transposition of our own irreducible estrangement to the otherness of languages. ${ }^{17}$ The ideas selected for points of departure are intended to refer to works born on the borderline between rhetoric and psychoanalysis. The reason for this is that they jointly provide us with a language and subject based foundation for accessing autobiographies which can be the starting point for the interpretation of the rhetoric of estrangement.

At this point, it would be relevant to make mention of what Freud referred to as the strange subconscious, which he likened to a strange language that is impossible to understand. ${ }^{18}$ It was from the point of view of the estrangement experience in psychoanalysis that Lacan faced the question of language or rhetoric. According to the contemporary theoretical approach to the rhetoric of estrangement, the concept of estrangement is a rhetorical phenomenon that can be explicated through the mutual replacement (displacement) of the psychoanalytical school represented by Lacan and the rhetorical reading related to de Man. The strangeness of the original language for the users of the mother tongue is exactly as threatening as the experience of the unconscious for the subject that has lost stability. Shoshana Felman notes that Freud likened the operation of suppression to translation, and understood it as the failure of translation. Lacan emphasized the possibility of the mutual enlightening of language and estrangement, or uncon- 
scious. Paul de Man was reluctant to appreciate the rhetorical transpositions of psychoanalysis. Nevertheless, this way of thinking was not totally alien to him, as long as rhetoric led him to posing the question concerning the relationship between language and the unconscious. As he pointed out, language serves the discourse of neither the conscious nor the unconscious, as it is exactly language that determines both:

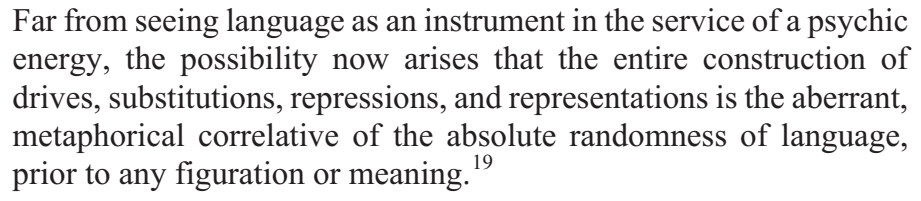

Far from seeing language as an instrument in the service of a psychic energy, the possibility now arises that the entire construction of drives, substitutions, repressions, and representations is the aberrant, metaphorical correlative of the absolute randomness of language, prior to any figuration or meaning. ${ }^{19}$

Put in the perspective of reading, this means that the recipients themselves are also participants in the rhetorical structure of the text.

Making a distinction between the rhetorical and the not-primarily-rhetorical reading of the rhetoric of estrangement may be quite legitimate. The latter, in its most comprehensive sense, undertakes the task of interpreting the rhetorical configurations that convey estrangement as an aesthetic experience. The narrato-poetical approach does not dismiss the examination of language based functioning, and renders the rhetoric of estrangement as aesthetic experience. First, it builds up the system of regulations that control autobiographical operation in such a way as Derrida identified the rules of the genre. ${ }^{20}$ Next, with the help of this interpretation, it finds the signifying processes that reorganize the principles of the genre. Regarding their effect, and depending on the context, the so-called disseminative language-based poetical procedures can also be understood as the manifestations of the rhetoric of estrangement. In this case, the interpretation conveys the experience of estrangement with the help of the identification of genre. Obviously, this depends on which concept of genre is taken as the starting point of interpretation. However, the interpretation of cultural estrangement appearing in autobiographical writings presents yet another new way of reading, the analysis of which will form the subject of another paper.

Notes

1 Szegedy-Maszák, Mihály (1986) "The Life and Times of the Autobiographical Novel”, Neohelicon, Vol. 13, No. 1, 83-104; Szávai, János (1988) Magyar emlékírók (Budapest: Szépirodalmi Kiadó); Kulcsár Szabó, Zoltán (1997) “A személyiségkonstrukció alakzatai a Tücsökzenében avagy egy antihumanista olvasat esélyei: Az olvasás lehetőségei”, Kijárat, 87-109; Séllei, Nóra (2001) Tükröm, tükröm ... Írónök életrajzai a 20. század elejéröl (Debrecen: Kossuth Egyetemi Kiadó); Bónus, Tibor (2002) Garaczi László (Pozsony: Kalligram), 98-178; Mekis D., János (2002) “Az önéletrajz mintázatai” (Budapest: FISZ). 
2 Bruss, Elizabeth W. (1976) Autobiographical Acts: The Changing Situation of a Literary Genre (Baltimore: Johns Hopkins UP); Derrida, Jacques (1988) Mémoires pour Paul de Man (Paris: Galilée); Olney, James (ed.) (1980) Autobiography: Essays Theoretical and Critical (New Jersey: Princeton); Schneider, Manfred (1986) Die erkaltete Herzensschrift. Der autobiographische Text im 20. Jahrhundert (München-Wien: Hanser); Olney, James (1988) Studies in Autobiography (New York: Oxford UP); Nalbantian, Suzanne (1994) Aesthetic Autobiography. From Life to Art in Marcel Proust, James Joyce, Virginia Woolf and Anaïs Nin (London: Macmillan).

3 Sprinker, Michael (1980) "Fictions of the Self: The End of Autobiography" in James Olney (ed.) Autobiography: Essays Theoretical and Critical (New Jersey: Princeton). 321-342; Bürger, Peter (2000) Das Verschwinden des Subjekts - Christa Bürger (2000) Das Denken des Lebens. Fragmente einer Geschichte der Subjektivität (Frankfurt: Suhrkamp). 211.

4 Derrida, Jacques (2001) 'Le ruban de machine à écrire. Limited Ink II', Papier Machine (Paris: Galilée). 33-147.

5 de Man, Paul (1979) 'Autobiography as De-facement', Modern Language Notes, Vol. 94. 919-930.

6 de Man, Paul (1982) 'Sign and Symbol in Hegel's Aesthetics', Critical Inquiry, Vol. 8. 767; Warminski, Andrzej (1987) Readings in Interpretation: Hegel, Heidegger, Hölderlin (Minneapolis: University of Minnesota Press).

7 Menke, Bettine (2000) Prosopopoeia. Stimme und Text bei Brentano, Hoffmann, Kleist und Kafka (München: Fink).

8 de Man, Paul (1979) 'Excuses (Confessions)' in Paul de Man Allegories of Reading. Figural Language in Rousseau, Nietzsche, Rilke and Proust (New Haven-London: Yale University Press). 278-301.

9 Fischer-Lichte, Erika (1999) Geschichte des Dramas. Epochen der Identität auf dem Theater von der Antike bis zur Gegenwart (Tübingen-Basel: Francke Verlag).

10 Iser, Wolfgang (1993) The Fictive and the Imaginary: Charting Literary Anthropology (Baltimore: Johns Hopkins University Press).

11 Lejeune, Philippe (1975) Le pacte in Philippe Lejeune Le pacte autobiographie (Paris: Seuil). $13-49$.

$12 \quad$ Ibid. 36.

13 Derrida, Jacques (1972) Signature événement contexte; Marges de la philosophie (Paris: Minuit).

14 Düsing, Wolfgang (1982) Erinnerung und Identität: Untersuchungen zu einem Erzählsproblem bei Musil, Döblin und Doderer (München); Foster, John Burt (1993) Nabokov's Art of Memory and European Modernism (Princeton: Princeton University Press); Guerard, Albert Joseph (1980) The Touch of Time: Myth, Memory and the Self (Stanford University Press); (1985) Journal of Memory and Language (New York: Academic Press); Morse, Jonathan (1990) Word by Word: The Language of Memory (Ithaca); Ricoeur, Paul (2000) La mémoire, l'histoire, l'oubli (Paris: Seuil); Neisser, Ulric and Fivush, Robin (eds) (1998) The Remembering Self: Construction and Accuracy in the Self-narrative (Cambridge: Cambridge University Press); Conway, Martin A. (ed.) (1992) Theoretical Perspectives on Autobiographical Memory (Dordrecht: Kluwer); Rubin, David C. (ed.) (1986) Autobiographical Memory (Cambridge: Cambridge University Press).

15 Waugh, Patricia (1984) Metafiction. The Theory and Practice of Self-conscious Fiction (London-New York: Methuen). 1-19; Pier, John - Schaeffer, Jean-Marie (eds) (2005) Métalepses. Entorses au pacte de la representation (Paris: EHESS).

16 de Man, Paul (1985) “Conclusions, Walter Benjamin's 'The Task of the Translator'”, Messenger Paper (Cornell University, Yale French Studies) Vol. 69. 25-46. 
17 Felman, Shoshana (1985) Writing and Madness - Literature - / Philosophy / Psychoanalysis (New York: Cornell University Press).

18 Felman, Shoshana (ed.) Yale French Studies 55/56 - Literature and Psychoanalysis - The Question of Reading: Otherwise (New Haven: Yale University Press). 2; Felman, Shoshana (1985) Writing and Madness - Literature - / Philosophy / Psychoanalysis (New York: Cornell University Press). 18.

19 de Man, Paul "Excuses (Confessions)". 299.

20 Derrida, Jacques (1986) La loi du genre (Paris: Parages). 264. 
